19 Revue d'histoire du XIXe siècle

Société d'histoire de la révolution de 1848 et des

révolutions du XIXe siècle

$6 \mid 1990$

Le XIXe siècle en question

Les paysanneries françaises face à la Seconde République

Jean-Luc Mayaud

OpenEdition

Journals

Electronic version

URL: http://journals.openedition.org/rh19/47

DOI: $10.4000 /$ rh 19.47

ISSN: 1777-5329

Publisher

La Société de 1848

Printed version

Date of publication: 1 June 1990

ISSN: 1265-1354

Electronic reference

Jean-Luc Mayaud, "Les paysanneries françaises face à la Seconde République », Revue d'histoire du XIXe siècle [Online], 6 | 1990, Online since 09 September 2008, connection on 01 May 2019. URL http://journals.openedition.org/rh19/47; DOI : 10.4000/rh19.47

This text was automatically generated on 1 May 2019.

Tous droits réservés 


\title{
Les paysanneries françaises face à la Seconde République
}

\author{
Jean-Luc Mayaud
}

\begin{abstract}
S
No abstract available by now

Pas de résumé disponible actuellement

INDEX

Mots-clés: Paysans, Seconde République
\end{abstract}

